\title{
Equity in Education Journal (EEJ)
}
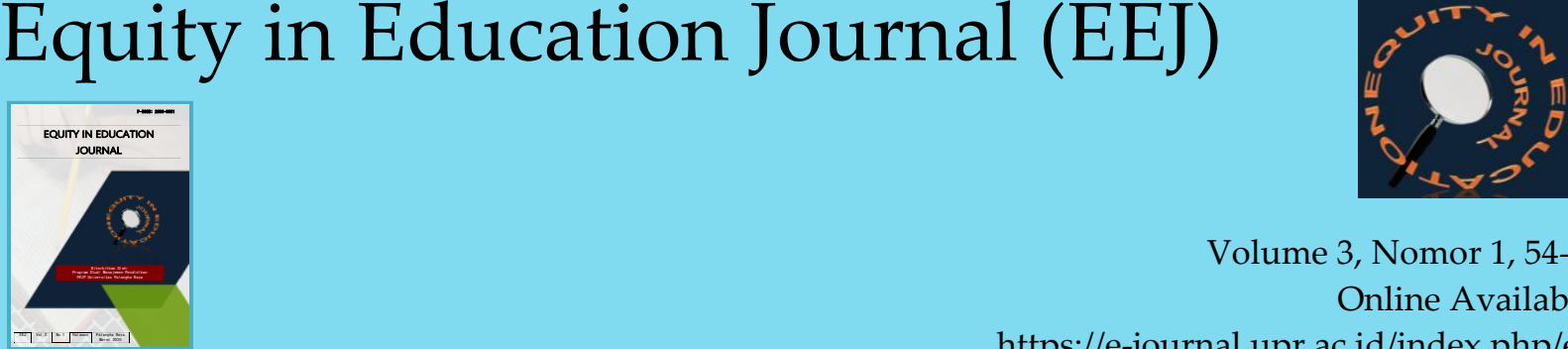

Volume 3, Nomor 1, 54-59

Online Available:

CEEJ 2021 All Rights Reserved

https://e-journal.upr.ac.id/index.php/eej ISSN: 2686-0031 (Print)

\section{IMPLEMENTASI KEGIATAN EKSTRAKURIKULER TILAWAH AL-QUR'AN DI MADRASAH IBTIDAIYAH NEGERI 1 KOTA PALANGKA RAYA}

\author{
Muhammad Taghab Ali*, Slamet Winaryo, Sumarnie \\ FKIP Universitas Palangka Raya, Palangka Raya
}

\begin{tabular}{l} 
Info Artikel \\
\hline Riwayat Artikel: \\
Diterima: Januari 2021 \\
Disetujui: Maret 2021 \\
\\
Kata Kunci: \\
Implementasi, Kegiatan \\
Ekstrakurikuler, Tilawah \\
Al-Qur'an, Madrasah \\
Ibtidaiyah Negeri 1, Kota \\
Palangka Raya.
\end{tabular}

Abstrak

Penelitian ini bertujuan untuk mendeskripsikan tentang Implementasi Kegiatan
Ekstrakurikuler Tilawah Al-Qur'an di Madrasah Ibtidaiyah Negeri 1 Kota Palangka
Raya. Penelitian ini menggunakan pendekatan kualitatif dengan rancangan studi kasus.
Sumber data dalam penelitian ini terdiri dari: Kepala Sekolah, Koordinator
Ekstrakurkuler dan Pembina Ekstrakurikuler. Teknik pengumpulan data dengan metode
observasi, wawancara dan studi dokumentasi. Analisis data menggunakan model
interaktif data. Pengabsahan data menggunakan teknik triangulasi. Hasil penelitian ini
menunjukan: (1) Perencanaan ekstrakurikuler Tilawah Al-Qur'an dilakukan kepala
sekolah melibatkan banyak pihak untuk membahas terkait perencanaan ekstrakurikuler
Tilawah Al-Qur'an untuk satu semester kedepan dengan pembentukan Tim, penentuan
koordinator, pembina, sarana dan prasarana, waktu pelaksanaan, pendanaan, perekrutan
peserta Tilawah; (2) Pengorganisasian ekstrakurikuler Tilawah Al-Qur'an dilakukan
dengan membuat SK pengangkatan koordinator dan pembina oleh kepala sekolah; (3)
Pelaksanaan ekstrakurikuler Tilawah Al-Qur'an dilakukan di musholla yang telah
tersedia sarana yang lengkap dengan jadwal hari selasa dan kamis pada jam 13.30
sampai dengan jam 14.30 WIB, dan (4) Pengawasan ekstrakurikuler Tilawah Al-Qur'an
dilakukan oleh kepala sekolah dan wakil kepala sekolah bidang kesiswaan.

Korespondensi:

Muhammad Taghab Ali*

FKIP, Universitas Palangka

Raya

E-mail:

aaljerangau@gmail.com Abstract

Abstract
This study aims to describe the implementation of extracurricular activities of recitation
of the Qur'an in Madrasah Ibtidaiyah Negeri 1 Palangka Raya City. This study used a
qualitative approach with case study design. Sources of data in this study consisted of:
the principal, the extracurricular coordinator and the extracurricular coach. Data
collection techniques using observation, interview and documentation study methods.
Data analysis using an interactive data model. The data validation used triangulation
technique. The results of this study indicate: (1) The principal's planning for
extracurricular recitation of the Qur'an involves many parties to discuss extracurricular
planning for the recitation of the Qur'an for the next semester by forming a team,
determining the coordinator, supervisor, facilities and infrastructure, implementation
time, funding, recruitment of recitation participants; (2) Organizing extracurricular
recitation of Al-Qur'an is done by making a decree for the appointment of a coordinator
and supervisor by the school principal; (3) Implementation of extracurricular recitation
of the Qur'an is carried out in a prayer room which has complete facilities with a
schedule on Tuesday and Thursday from 13.30 to 14.30 WIB, and (4) Supervision of
extracurricular recitation of the Al-Qur'an is carried out by the head school and vice
principal of student affairs.

\section{PENDAHULUAN}

Pendidikan merupakan proses perubahan atau pengembangan diri anak didik dalam segala aspek kehidupan sehingga terbentuklah suatu kepribadian yang utuh (insan kamil) dalam arti memiliki akhlak yang baik, sebagai makhluk sosial, maupun makhluk individu, sehingga dapat beradaptasi dan hidup dalam masyarakat luas dengan baik. Secara tegas upaya untuk menciptakan 
sumber daya manusia yang berkualitas tersebut tertuang dalam fungsi dan tujuan pendidikan Bab II pasal 3 Undang-Undang Nomor 20 tahun 2003 tentang Sistem Pendidikan Nasional menyebutkan bahwa: "Pendidikan nasional berfungsi mengembangkan kemampuan dan membentuk watak serta peradaban bangsa yang bermartabat dalam rangka mencerdaskan kehidupan bangsa, bertujuan untuk berkembangnya potensi peserta didik agar menjadi manusia yang beriman dan bertakwa kepada Tuhan Yang Maha Esa, berakhlak mulia, sehat, berilmu, cakap, kreatif, mandiri, dan menjadi warga Negara yang demokratis serta bertanggung jawab".

Namun dengan [esatnya perkembangan Ilmu Pengetahuan dan Teknologi (IPTEK), seperti internet di era globalisasi bisa menyebabkan bergesernya nilai-nilai akhlak anak bangsa karena perkembangan Ilmu Pengetahuan dan Teknologi (IPTEK) tersebut sehingga sulit untuk mencapai tujuan pendidikan. Perkembangan IPTEK akan terus berkembang seiring dengan perkembangan zaman, sehingga harus diimbangi dengan pengetahuan dan penguatan Iman dan Taqwa (IMTAQ) di suatu lembaga pendidikan, agar antara keduanya seimbang antara ilmu pengetahuan teknologi dan ilmu agama, maka anak-anak harus di berikan filter yang kuat dengan dibekali penanaman nilai-nilai karakter religius.

Untuk membentuk watak dan karakter serta pengembangan diri dalam rangka mencerdaskan kehidupan bangsa sehingga terciptanya watak dan juga karakter peserta didik tidak cukup hanya diberikan materi yang terdapat dalam kurikulum yang ada dan berlaku di sekolah, melainkan juga perlu adanya kegiatan-kegiatan tambahan di luar kurikulum pelajaran. Kegiatan tambahan tersebut dikemas dalam sebuah program yang dapat menunjang menanamkan nilai-nilai karakter religius peserta didik. Salah satu wadah menanamkan nilai-nilai karakter religius peserta didik di sekolah adalah kegiatan ekstrakurikuler. Permendikbud No. 62 Tahun 2014 menjelaskan bahwa kegiatan ekstrakurikuler merupakan kegiatan yang dilakukan oleh peserta didik di luar jam belajar kegiatan intrakurikuler dan kegiatan kokurikuler, di bawah bimbingan dan pengawasan satuan pendidikan, bertujuan untuk mengembangkan potensi, bakat, minat, kemampuan, kepribadian, kerjasama, dan kemandirian peserta didik secara optimal untuk mendukung pencapaian tujuan pendidikan". Menurut Wahjosumidjo (dalam Kompri, 2015) kegiatan ekstrakurikuler merupakan kegiatan-kegiatan siswa di luar jam pelajaran, yang dilaksanakan di sekolah maupun di luar sekolah dengan tujuan untuk memperluas pengetahuan, memahami keterkaitan antar berbagai mata pelajaran, penyaluran bakat dan minat, dan dalam rangka usaha untuk meningkatkan kualitas keimanan dan ketakwaan para siswa terhadap Tuhan Yang Maha Esa, kesadaran berbangsa dan bernegara, berbudi pekerti luhur, dan sebagainya. Sejalan dengan pernyataan tersebut Noor (2012) menjelaskan ekstrakurikuler merupakan kegiatan pendidikan diluar mata pelajaran dan pelayanan konseling untuk membantu pengembangan peserta didik sesuai dengan kebutuhan, potensi, bakat dan minat mereka melalui kegiatan yang khusus diselenggarakan oleh pendidik dan atau tenaga kependidikan yang berkemampuan dan berwewenang di sekolah/madrasah. Jadi ekstrakurikuler adalah kegiatan diluar jam pelajaran yang dilakukan, baik di sekolah ataupun di luar sekolah yang bertujuan untuk memperdalam dan memperkaya pengatahuan siswa, mengenal hubungan antar berbagai pelajaran, serta menyalurkan bakat dan minat.

Tilawatil Al-Qur'an berasal dari kata Tilawah dan Al-Qur'an. Tilawah menurut kamus besar bahasa Indonesia memiliki arti pembacaan (ayat Al-Qur'an) dengan baik dan indah. Sedangkan Al-Qur'an ialah kitab suci umat Islam yang berisi firman Allah SWT yang diturunkan kepada Nabi Muhammad SAW dengan perantaraan Malaikat Jibril untuk dibaca, dipahami, dan diamalkan sebagai petunjuk atau pedoman hidup bagi umat manusia. Sedangkan secara istilah adalah membaca Al-Qur'an dengan bacaan yang menjelaskan huruf-hurufnya yang berhati-hati dalam melaksanakan bacaannya agar lebih mudah memahami makna yang terkandung di dalamnya. Dengan program ekstrakurikuler tilawah Al-Qur'an tersebut peserta didik akan dapat meningkatkan keimanan dan ketaatan pada ajaran agama yang dianutnya, sehingga mempunyai karakter religius yang mumpuni sesuai Peraturan Presiden Republik Indonesia Nomor 87 Tahun 2017 untuk mencapai karakter religius dan karakter integritas. Ekstrakurikuler Tilawah Al-Qur'an merupakan bagian yang dimuat dalam kurikulum madrasah karena kegiatan ini bertujuan agar 
peserta didik mempunyai kemampuan membaca Al-Qur'an secara baik dan benar serta bertilawah. Menurut Ishak (2017) madrasah memiliki basis kurikulum keagamaan, sama halnya dengan pesantren, tapi sedikit sekali program-program madrasah menggunakan cara-cara yang diterapkan di pesantren, salah satunya adanya pendidikan Tilawah Al-Qur'an secara berlagu. Dengan adanya kegiatan ekstrakurikuler Tilawah Al-Qur'an akan membantu siswa dalam menguatkan karakter religiusnya dan mengembangkan bakat dan minat siswa dalam bertilawah Al-Qur'an. Pada kegiatan ekstrakurikuler Tilawah Al-Qur'an tentunya tetap melibatkan siswa dalam kegiatan secara aktif. Selain itu adanya motivasi guru untuk tetap membimbing anak didiknya agar selalu membaca Al-Qur'an. Dalam hal ini juga akan memperkuat minat siswa dalam memiliki keterampilan khususnya bertilawah Al-Qur'an.

Secara umum tujuan penelitian ini adalah untuk mendeskripsikan tentang Implementasi Kegiatan Ekstrakurikuler Tilawah Al-Qur'an di Madrasah Ibtidaiyah Negeri 1 Kota Palangka Raya, dilihat dari aspek: (1) Perencanaan ekstrakurikuler Tilawah Al-Qur'an, (2) Pengorganisasian Ekstrakurikuler Tilawah Al-Qur'an, (3) Pelaksanaan Ekstrakurikuler Tilawah Al-qur'an, dan (4) Pengawasan Ekstrakurikuler Tilawah Al-Qur'an.

\section{METODE}

Penelitian ini merupakan penelitian kualitatif. Sugiyono (2011) menjelaskan bahwa metode kualitatif digunakan untuk mendapatkan data yang mendalam, suatu data yang mengandung makna. Teknik Pengumpulan data yang digunakan dalam penelitian ini yaitu: metode observasi sebagai pengamatan dan pencatatan yang tampak pada objek. Hal ini sejalan dengan pendapat Riduwan (2013) observasi yaitu melakukan pengamatan secara langsung ke objek penelitian untuk melihat dari dekat kegiatan yang dilakukan. Dalam metode wawancara pewawancara mengajukan pertanyaan kepada yang diwawancari. Moleong (2012) mendefinisikan wawancara sebagai percakapan dengan maksud tertentu. Percakapan itu dilakukan oleh dua pihak, yaitu pewawancara (interviewer) yang mengajukan pertanyaan dan yang diwawancarai (interview) yang memberikan jawaban atas pertanyaan itu. Dokumentasi merupakan metode yang digunakan peneliti untuk mengumpulkan data-data dengan menyelidiki benda-benda tertulis seperti buku-buku, majalah, dokumen, peraturan-peraturan, dan lain sebagainya. Arikunto (2002) menyatakan metode dokumentasi adalah mencari data yang berupa catatan, transkrip, buku, surat kabar, majalah, prasasti, notulen rapat, legger, agenda dan sebagainya.

Sugiyono, (2011) menyatakan yang dimaksud analisis data adalah proses mencari dan menyusun secara sistematis data yang diperoleh dari hasil wawancara, catatan lapangan, dan dokumentasi dengan cara mengorganisasikan data ke kategori, menjabarkan ke dalam unit-unit, melakukan sintesa, menyusun ke dalam pola, memilih yang penting dan akan dipeajari, dan membuat kesimpulan sehingga mudah dipahami oleh diri sendiri dan orang lain. Miles \& Huberman (dalam Sugiyono, 2008) mengemukakan aktivitas dalam analisis data kualitatif harus dilakukan secara terus menerus sampai tuntas, sehingga datanya sudah jenuh. Analisis data dalam penelitian ini menggunakan model interaktif data meliputi: Reduksi data, Penyajian data, dan Penarikan kesimpulan. Pengabsahan Data dalam penelitian ini menggunakan teknik Triangulasi dan member check. Menurut Moleong (2012) untuk menetapkan keabsahan data (trustworthiness) data diperlukan teknik pemeriksaan, salah satunya dengan teknik Triangulasi. Sedangkan member check adalah proses pengecekan data yang diperoleh peneliti kepada pemberi data (Sugiyono, 2014).

\section{HASIL DAN PEMBAHASAN \\ Perencanaan Ekstrakurikuler Tilawah Al-Qur'an}

Berdasarkan hasil temuan penelitian diketahui bahwa perencanaan ekstrakurikuler Tilawah Al-Qur'an di Madrasah Ibtidaiyah Negeri 1 Kota Palangka Raya dilakukan dengan: (1) memasukan program Ekstrakurikuler Tilawah al-qur'an ke dalam kurikulum Madrasah sebagai 
program untuk mendukung meningkatkan kualitas peserta didik dari pada kegiatan intrakurikuler khususnya untuk meningkatkan kemampuan membaca al-qur'an seperti munaqosah tahfidzul qur'an. Ishak (2017) menyatakan madrasah memiliki basis kurikulum keagamaan, sama halnya dengan pesantren, tapi sedikit sekali program-program madrasah menggunakan cara-cara yang diterapkan di pesantren, salah satunya adanya pendidikan Tilawah Al-Qur'an secara berlagu; (2) Dalam proses perencanaan ekstrakurikuler tilawah Al-Qur'an ini kepala sekolah melibatkan banyak pihak yaitu: Waka. Kurikulum, Waka. Kesiswaan, Waka. Humas dan Waka Sarpras, Koordinator kegiatan ekstrakurikuler, dan Pembina Ekstrakurikuler. Moedjiarto (dalam Sagala, 2009) menyatakan pengikutsertaan ini akan menimbulkan perasaan ikut memiliki yang dapat memberikan dorongan kepada guru dan personel sekolah yang lain untuk berusaha agar rencana tersebut berhasil; (3) Direncanakan pada awal tahun ajaran dengan Pembentukan Tim Kerja, Penentuan Koordinator Kegiatan Ekstrakurikuler Tilawah Al-Qur'an, yaitu sebagai penanggung jawab kegiatan. Sedangkan Pembina Ekstrakurikuler Tilawah Al-Qur'an bertugas sebagai pelatih peserta didik dalam bertilawah; (4) Penentuan Sarana dan Prasarana dilakukan untuk pendukung jalannya proses kegiatan pembinaan; (5) Penentuan waktu pelaksanaan dilakukan untuk menetapkan jadwal pelaksanaan kegiatan; (6 Penentuan Pendanaan, dilakukan untuk membeli berbagai kebutuhan-kebutuhan yang diperlukan; dan (7) Penentuan perekrutan peserta tilawah untuk mengakomodir siswa yang akan mengikuti kegiatan ekstrakurikuler. Temuan penelitian ini sejalan dengan pendapat Nawawi (2003) bahwa perencanaan merupakan proses pemilihan dan penetapan tujuan, strategi, metode, anggaran, dan standar (tolak ukur) keberhasilan suatu kegiatan.

\section{Pengorganisasian Kegiatan Ekstrakurikuler Tilawah Al-Qur'an}

Berdasarkan hasil temuan penelitian diketahui bahwa dalam proses pengorganisasian kepala sekolah melalui forum rapat dengan Tim yang telah dibentuk untuk menentukan terlebih dahulu koordinator Tilawah Al-Qur'an dan pembina Tilawah Al-Qur'an. Selanjutnya membuat SK. pengangkatan/penunjukan koordinator ekstrakurikuler dan pembina ekstrakurikuler Tilawah Al-Qur'an kemudian akan membuat struktur organisasi ekstrakurikuler Tilawah Al-Qur'an. Temuan ini sejalan dengan pendapat Hasibuan (2014) bahwa organisasi sebagai proses penentuan dan pengelompokkan pekerjaan yang akan dikerjakan, menetapkan dan melimpahkan wewenang dan tanggung jawab dengan maksud untuk memungkinkan orang-orang bekerja sama secara efektif dalam mencapai tujuan. Sejalan dengan pendapat tersebut, Utomo (1986) menyatakan bahwa suatu organisasi sosial mempunyai perumusan tertulis yang jelas dalam hal tujuan, peraturan-peraturan (berupa anggaran dasar, anggaran rumah tangga, dan sebagainya), prosedur penentuan atau regulasi (misalnya surat keputusan dan sebagainya) serta kebijaksanaannya.

\section{Pelaksanaan Ekstrakurikuler Tilawah Al-Qur'an}

Berdasarkan hasil temuan penelitian diketahui bahwa proses pelaksanaan ekstrakurikuler Tilawah Al-Qur'an di MIN 1 Kota Palangka Raya yaitu: (1) dilaksanakan diluar jam pembelajaran dengan mengikuti jadwal yang telah ditetapkan sebelumnya dalam forum rapat yaitu, dilaksanakan pada hari selasa dan kamis pada Pukul (13.30) sampai dengan jam (14.30) WIB. Penjelasan tersebut sejalan dengan menurut Permendikbud No. 62 Tahun 2014 menjelaskan bahwa kegiatan ekstrakurikuler adalah kegiatan yang dilakukan oleh peserta didik di luar jam belajar kegiatan intrakurikuler dan kegiatan kokurikuler, di bawah bimbingan dan pengawasan satuan pendidikan, bertujuan untuk mengembangkan potensi, bakat, minat, kemampuan, kepribadian, kerjasama, dan kemandirian peserta didik secara optimal untuk mendukung pencapaian tujuan pendidikan; (2) proses pelaksanaan ekstrakurikuler Tilawah Al-Qur'an dilakukan dengan pengumpulan peserta Tilawah Al-Qur'an., melakukan Do'a, mengabsen peserta tilawah, apersepsi, memberikan latihan dengan menuliskan ayat Al-Qur'an yang akan dipelajari, di baca bersama-sama oleh peserta, menyelipkan materi tajwid dan makhrajal di tiap-tiap ayat Tilawah Al-Qur'an., mentadabur ayat Tilawah Al-Qur'an, dan diakhiri dengan bacaan Hamdallah dan menutupnya dengan salam. Temuan ini sejalan dengan pendapat Rouf, (2004) bahwa talaqqi adalah metode pengajaran alQuran yang diterapkan Rasulullah SAW. Seorang guru dan seorang murid berinteraksi secara 
langsung dan ada proses koreksi dan menyimak dalam metode itu. Terry (1993) menyatakan penggerakan merupakan aktualisasi dari perencanaan dan pengorganisasian secara kongkrit. Perencanaan dan pengorganisasian tidak akan mencapai tujuan yang ditetapkan tanpa adanya aktualisasi dalam bentuk kegiatan. Singkatnya actuating mencakup kegiatan yang dilakukan seorang yang ditetapkan pemimpin untuk mengawali dan melanjutkan kegiatan yang telah di tetapkan oleh unsur perencanaan dan pengorganisasian agar tujuan-tujuan dapat tercapai.

\section{Pengawasan Ekstrakurikuler Tilawah Al-Qur'an}

Berdasarkan hasil temuan penelitian diketahui bahwa proses pengawasan ekstrakurikuler Tilawah Al-Qur'an dilakukan oleh kepala sekolah yaitu pada setiap latihan kegiatan ekstrakurikuler berlangsung dalam waktu tertentu atau secara tiba-tiba. Pengawasan diselenggarakan guna mengetahui berjalannya atau tidak kegiatan ekstrakurikuler dan untuk mengetahui tingkat keberhasilan dalam mencapai tujuan yang ingin dicapai. Selain itu pengawasan juga dilakukan oleh Waka. Kesiswaan, yaitu melakukan pengawasan dengan keberlanjutan pada setiap kegiatan ekstrakurikuler berlangsung. Temuan tersebut sejalan dengan pendapat Siagian (2003) bahwa pengawasan merupakan proses pengamatan dari pelaksanaan seluruh kegiatan organisasi untuk menjamin agar semua pekerjaan yang sedang dilakukan berjalan sesuai dengan rencana yang telah ditentukan sebelumnya. Sejalan dengan pendapat tersebut Aedi (2016) menyatakan peran penting kepala sekolah sebagai supervisor adalah memberikan kontribusi yang bersifat membina, membimbing, dan mengarahkan perkembangan para personel sekolah.

\section{SIMPULAN}

Berdasarkan hasil dan pembahasan dapat disimpulkan bahwa: (1) Perencanaan ekstrakurikuler Tilawah Al-Qur'an direncanakan dengan melibatkan banyak pihak, dilakukan dengan proses pembentukan TIM kerja yang dikemudian akan membahas terkait persiapan kegiatan Ekstrakurikuler Tilawah Al-Qur'an; (2) Pengorganisasian ekstrakurikuler Tilawah AlQur'an ditetapkan dengan SK Kepala Sekolah Madrasah yang terdiri atas Koordinator Ekstrakurikuler sebagai penanggung jawab dan Pembina Ekstrakurikuler sebagai pelatih; (3) Pelaksanaan ekstrakurikuler tilawah al-qur'an dilakukan di musholla yang telah tersedia sarana yang lengkap dengan jadwal hari selasa dan kamis pada jam 13.30 sampai dengan jam 14.30 WIB, dengan materi yang telah disiapkan oleh Pembina; dan (4) Pengawasan ekstrakurikuler Tilawah Al-Qur'an dilaksanakan langsung oleh kepala sekolah dalam waktu-waktu tertentu, dan Waka. Kesiswaan dalam setiap berlangsungnya kegiatan dan keberlanjutannya.

\section{UCAPAN TERIMA KASIH}

Ucapan terima kasih penulis sampaikan kepada Kepala Madrasah beserta Bapak/Ibu Guru serta Pembina Ekstrakurikuler Tilawah Al-Qur'an di lingkungan Madrasah Ibtidaiyah Negeri 1 Kota Palangka Raya yang telah memberikan kesempatan serta dukungan penuh bagi penulis dalam melakukan seluruh proses penelitian. Penulis juga menyampaikan terima kasih kepada redaksi Equity in Education Journal (EEJ) Program Studi Manajemen Pendidikan FKIP Universitas Palangka Raya yang telah memberikan kesempatan artikel kami ini dapat dipublikasikan dalam jurnal ini.

\section{DAFTAR PUSTAKA}

Aedi, N. (2016). Manajemen Pendidik \& Tenaga Pendidikan. Yogyakarta: Gosyen Publishing. Arikunto, S. (2010). Prosedur Penelitian. Jakarta: PT. Rineka Cipta.

Ishak, M. (2017). Pelaksanaan Program Tilawah Alquran dalam Meningkatkan Kemampuan Membaca Alqur'an Siswa di MAS Al Ma'sum Stabat. Jurnal Edu Religia, 1(4): 602-617. Kompri. (2015). Manajemen Pendidikan. Yogyakarta: Ar-Ruzz Media. 
Malayu, S. P. H. (2014). Organisasi dan Motivasi: Dasar Peningkatan Produktivitas. Jakarta: Bumi Aksara.

Miles, B. M. \& Huberman, M. (1992). Analisis Data Kualitatif: Buku Sumber tentang MetodeMetode Baru. Jakarta: Penerbit Universitas Indonesia.

Moleong, L. J. (2012). Metode Penelitian Kualitatif. Bandung: PT. Remaja Rosdakarya.

Nawawi, H. (2003). Manajemen Sumber Daya Manusia. Yogyakarta: Gajah Mada University.

Noor, R. M. (2012). The Hidden Curriculum: Membangun Karakter melalui Kegiatan Ekstrakurikuler. Yogyakarta: Insan Madani.

Peraturan Menteri Pendidikan dan Kebudayaan Republik Indonesia Nomor 62 Tahun 2014 tentang Kegiatan Ekstrakurikuler pada Pendidikan Dasar dan Pendidikan Menengah.

Peraturan Presiden Republik Indonesia Nomor 87 Tahun 2017 tentang Penguatan Pendidikan Karakter.

Riduwan. (2013). Metode dan Teknik Menyusun Tesis. Bandung: Alfabeta.

Rouf, A. A. (2004). Tarbiyah Syakhsiyah Qur'aniyah (Membangun Kepribadian Qur'ani). Jakarta: Markaz Al Qur'an.

Sagala, S. (2009). Konsep dan Makna Pembelajaran. Bandung: Alfabeta.

Siagian, S. P. (2003). Teori \& Praktek Kepemimpinan. Jakarta: Rineka Cipta.

Sugiyono. (2011). Metode Penelitian Kuantitatif, Kualitatif dan R\&D. Bandung: Afabeta

Sugiyono. (2014). Metodologi Penelitian Manajemen. Bandung: Alfabeta.

Sugiyono. (2015). Metode Penelitian Kuantitatif, Kualitatif dan R\&D. Bandung: PT. Alfabeta.

Terry, G. R. (1993). Prinsip-prinsip Manajemen. Jakarta: Bumi Aksara.

Undang-Undang Nomor 20 Tahun 2003 tentang Sistem Pendidikan Nasional.

Utomo, S. B. (1986). Ilmu Sosial Dasar. Bogor: Universitas Pakuan. 